\title{
NDRG2 plays a pivotal role in ATLL leukaemogenesis by regulating the PTEN-mediated PI3K/AKT signalling pathway
}

\author{
Shingo Nakahata', Tomonaga Ichikawa', Yusuke Saito', Yasuhito Arai ${ }^{2}$, Tomohiko Taki ${ }^{3}$, Masafumi Taniwaki ${ }^{4}$, \\ Kazuhiro Morishita ${ }^{1 *}$
}

From 16th International Conference on Human Retroviruses: HTLV and Related Viruses

Montreal, Canada. 26-30 June 2013

Adult T-cell leukemia/lymphoma (ATLL) is a rare and aggressive T-cell leukemia/lymphoma that is etiologically linked to infection by human T-cell lymphotropic virus type 1 (HTLV-1). To find candidate causative genes for ATLL development, we used an integrative genomic analysis of ATLL and identified N-myc downstreamregulated gene 2 (NDRG2) as a candidate tumour suppressor gene on chromosome 14q11. Here we demonstrate that NDRG2 is a novel PTEN-interacting protein and recruits protein phosphatase $2 \mathrm{~A}$ to facilitate the dephosphorylation of PTEN at the Ser380, Thr382, and Thr383 (STT) cluster within the C terminus. Although the PI3K/ AKT signalling pathway is frequently activated in ATLL cells, neither the genetic alterations of the PTEN and PIK3CA genes nor the transcriptional down-regulation of PTEN expression were detected in ATLL. We found that activation of the PI3K/AKT signalling pathway in ATLL is mediated through hyperphosphorylation of PTEN-STT, a well-known mechanism of PTEN inactivation, by down-regulation of NDRG2 expression. Moreover, we found that NDRG2 deficiency in mice results in constitutive PI3K/AKT activation in various organs and high incidence of T-cell lymphoma and other types of cancer. Since down-regulation of NDRG2 expression via promoter methylation has been reported in various types of cancer, activation of the PI3K/AKT pathway by the enhanced PTEN-STT phosphorylation through the inactivation of NDRG2 is crucial for the development of a wide range of cancer cells including ATLL, which harbor no activating genetic alterations in the PI3K/AKT pathway.

\footnotetext{
* Correspondence: kmorishi@fc.miyazaki-u.ac.jp

'Division of Tumor and Cellular Biochemistry, Department of Medical

Sciences, University of Miyazaki, Kiyotake, Miyazaki, Japan

Full list of author information is available at the end of the article
}

\section{Authors' details}

'Division of Tumor and Cellular Biochemistry, Department of Medical Sciences, University of Miyazaki, Kiyotake, Miyazaki, Japan. ${ }^{2}$ Division of Cancer Genomics, National Cancer Center Research Institute, Chuo-ku, Tokyo, Japan. ${ }^{3}$ Department of Molecular Diagnostics and Therapeutics, Kyoto Prefectural University of Medicine, Kamigyo-ku, Kyoto, Japan. ${ }^{4}$ Department of Molecular Hematology and Oncology, Kyoto Prefectural University of Medicine, Kamigyo-ku, Kyoto, Japan.

Published: 7 January 2014

doi:10.1186/1742-4690-11-S1-P87

Cite this article as: Nakahata et al:: NDRG2 plays a pivotal role in ATLL leukaemogenesis by regulating the PTEN-mediated PI3K/AKT signalling pathway. Retrovirology 2014 11(Suppl 1):P87.

\section{Submit your next manuscript to BioMed Central and take full advantage of: \\ - Convenient online submission \\ - Thorough peer review \\ - No space constraints or color figure charges \\ - Immediate publication on acceptance \\ - Inclusion in PubMed, CAS, Scopus and Google Scholar \\ - Research which is freely available for redistribution \\ Submit your manuscript at www.biomedcentral.com/submit}

